Lubis, TM. et al. Penyuluhan Hukum Dampak Media Sosial Bagi Remaja.

\title{
PENYULUHAN HUKUM DAMPAK MEDIA SOSIAL BAGI REMAJA
}

\author{
Tri Murti Lubis ${ }^{1}$ \\ Syarifah Lisa Andriati ${ }^{2}$ \\ Detania Sukarja ${ }^{3}$ \\ 1,2,3 Fakultas Hukum Universitas Sumatera Utara \\ trimurti@usu.ac.id \\ syarifah lisa andriati@usu.ac.id \\ detasukarja@usu.ac.id
}

\begin{abstract}
Teenagers are the next generation of the nation that must continously be fostered to shape their identity and personality in accordance with Indonesian values. Various problems related to adolescents both as objects and as subjects have emerged with the development of information technology. Information technology has developed since the discovery and development of Science in the field of information and communication, starting from the development of communication system to communication equipment and direct and interactive communication tools. Social media is like a double-edged knife. If used wisely, selectively and responsibly, various social networking sites can be useful and beneficial. However, if used irresponsibly, social media can bring bad results, even legal problems. Therefore, social media users should be more careful in using the platform. The growing usage of social media among teenagers may bring negative impact if not addressed wisely due to teenagers' vulnerability. The lack of legal knowledge on the use of social media may also cause adolescents becoming perpetrators and/or victims of social media.
\end{abstract}

Keyword: Social media, legal problem, teenagers.

\section{PENDAHULUAN}

SMA Dharma Wanita Persatuan Prov.Sumut dan SMP Dharma Wanita Pelwildasu Medan adalah sekolah yang terletak di Kecamatan Medan Selayang yakni di Jalan Melati II Ujung No.30 Komplek Pemdasu Tanjung Sari, Kelurahan SempakataKecamatan Medan Selayang. Di SMA Dharma Wanita Persatuan Prov.Sumut dan SMP Dharma Wanita Pelwildasu berada di naungan Yayasan Pertiwi Dharma Wanita Pemprovsu. Salah satu dari sekolah adalah SMA Dharma Wanita Persatuan Prov.Sumut yang didirikan pada tahun pelaran 2003/2004. Jumlah kelas SMA Dharma Wanita Persatuan Prov.Sumut adalah sebanyak 3 Kelas yaitu Kelas 10, Kelas 11, dan Kelas 12. Jumlah total siswa di SMA
Dharma Wanita Persatuan Prov.Sumut adalah berjumlah 54 siswa.

Remaja merupakan generasi penerus Bangsa yang harus terus dibina dalam membentuk jati diri dan kepribadiannya sesuai dengan nilai-nilai yang ada di Indonesia. Munculnya berbagai persoalan yang berkaitan dengan remaja baik remaja sebagai objek maupun sebagai subjek.

Media sosial diibaratkan seperti pisau bermata dua. Jika digunakan dengan cara-cara bijaksana, selektif serta bertanggung jawab, berbagai situs jejaring sosial dapat bermanfaat, tetapi bila digunakan dengan tidak bertanggung jawab, media sosial dapat mendatangkan akibat yang tidak baik, bahkan bisa mendapat masalah hukum, maka sebaiknya lebih berhati-hati dalam menggunakan media sosial. 
Lubis, TM. et al. Penyuluhan Hukum Dampak Media Sosial Bagi Remaja.

Perkembangan teknologi informasi telah berkembang sejak penemuan dan pengembangan Ilmu di bidang informasi dan komunikasi, sehingga mampu menciptakan alat-alat pengembangan yang mendukung perkembangan teknologi informasi; itu dimulai dari sistem komunikasi sampai komunikasi peralatan alat komunikasi langsung serta dua arah (interaktif). Kemajuan teknologi telah menyebabkan banyak media interaksi sosial dan sering disebut jejaring sosial.

Seiring dengan perkembangan ilmu pengetahuan dan teknologi maka kehidupan manusia semakin berkembang dinamis terutama di bidang informasi dan komunikasi. Era Cyber telah menghasilkan teknologi internet dan membawa fenomena baru di bidang media massa yang juga melahirkan media baru yang lazimnya disebut media sosial atau jejaring sosial.

Media sosial adalah sebuah media online, dengan para penggunanya bisa dengan mudah berpartisipasi, berbagi, dan menciptakan isi meliputi blog, jejaring sosial, wiki, forum dan dunia virtual. Blog, jejaring sosial dan wiki merupakan bentuk media sosial yang paling umum digunakan oleh masyarakat di seluruh dunia.

\section{Andreas}

Kaplan dan Michael Haenlein mendefinisikan media sosial sebagai "sebuah kelompok aplikasi berbasis internet yang membangun di atas dasar ideologi dan teknologi Web 2.0 , dan yang memungkinkan penciptaan dan pertukaran user-generated content".

Jumlah pemakai internet di Indonesia mencapai 70 juta atau $28 \%$ dari total populasi. Pemakai medsos seperti Facebook berjumlah sekitar 50 juta atau $20 \%$ dari total populasi, sementara pengguna Twitter mencapai 40 juta atau $16 \%$ dari total populasi. Angka-angka di atas dari tahun ke tahun bakal terus bertumbuh, karena ditopang olehbasis pemakai mobile/telepon seluler dan internet yang besar. Pengeluaran TIK per kapita pun lumayan tinggi, yakni US\$132 per tahun dan pertumbuhan pendapatan industri TIK 7-10\% per tahun.
Perkembangan dari media sosial ini sungguh pesat, ini bisa di lihat dari banyaknya jumlah anggota yang di miliki masing masing situs jejaring sosial ini, berikut tabel jumlah anggota dari masing - masing situs yang di kutip dari (August E. Grant:297) pada 1 Mei 2010:

\begin{tabular}{|l|l|l|}
\hline No. & Nama Situs & Jumlah Member \\
\hline 1 & Facebook & 250.000 .000 \\
\hline 2 & Myspace & 122.000 .000 \\
\hline 3 & Twitter & 80.500 .000 \\
\hline 4 & Linkedin & 50.000 .000 \\
\hline 5 & Ning & 42.000 .000 \\
\hline \multicolumn{2}{|c|}{ Dari beberapa data menunjukkan } \\
\hline
\end{tabular}

bahwa penduduk Indonesia termasuk pengguna situs media sosial facebook dan twitter yang cukup banyak, berdasarkan rilis data www.checkfacebook.com per tanggal 20 Juli 2012, sebanyak 44.074.560 juta orang kita menggunakan facebook. Hal ini menempatkan Indonesia pada urutan keempat di dunia dalam penggunaan facebook setelah Negara Amerika, Brasil, dan India, sementara, dalam urutan pengguna media social twitter, mengutip data yang dilansir dari situs semiocast.com, Indonesia berada pada urutan lima setelah Amerika Serikat, Brazil, Jepang, dan Inggris dengan pengguna sekitar 19,5 juta. Menurut data yang dikeluarkan salingsilang.com dan aworldoftweets.com per tanggal 20 Juli 2012.

Andi Hamzah menyatakan bahwa:

Teknologi internet membawa manusia pada peradaban baru, dimana terjadi perpindahan realitas kehidupan dari aktifitas nyata ke aktivitas maya (virtual) yang disebut dengan istilah cyberspace.

Kemajuan teknologi berkembang sangat pesat, mulai dari media elektronik, transportasi, dan teknologi yang menunjang kinerja masyarakat. Dengan adanya teknologi, mobilitas, dan pekerjaan menjadi semakin mudah. Salah satunya adalah bidang Ilmu Pengetahuan Teknologi dan informasi (IPTEK) dengan adanya jaringan interconnected network (internet). Kemudahan penggunaannya dapat membantu masyarakat untuk menemukan hal-hal baru yang belum 
Lubis, TM. et al. Penyuluhan Hukum Dampak Media Sosial Bagi Remaja.

pernah mereka ketahui. Jaringan internet juga berpengaruh pada perkembangan sarana komunikasi. Media sosial adalah salah satu contoh sarana komunikasi untuk saling berbagi informasi.

Agus Raharjo dalam buku nya cybercrime pemahaman dan upaya pencegahan kejahatan berteknologi menyatakan bahwa :

Teknologi informasi dan komunikasi juga telah mengubah perilaku dan pola hidup masyarakat secara global, dan menyebabkan dunia menjadi tanpa batas (borderless), serta menimbulkan perubahan di berbagai bidang kehidupan.

Media sosial adalah media online yang berfungsi sebagai sarana berinteraksi antar individu maupun kelompok di dunia maya. Pengguna media sosial mulai bertambah seiring dengan pertumbuhan penduduk. Pengguna internet aktif di seluruh dunia mencapai 3,17 miliar. Pertumbuhan rata-rata pengguna internet per tahun yaitu 7,6\%. Pengguna handphone semakin bertambah seiring dengan penambahan fitur yang semakin modern dan baru.

Semakin berkembangnya penggunaan media sosial di satu sisi memberikan manfaat bagi penggunanya, akan tetapi di sisi lain akan berdampak negatif apabila tidak disikapi dengan bijak oleh penggunanya terutama kalangan remaja yang masih rentan terkena dampak negatif dari penggunaan media sosial. Kurangnya pengetahuan yang terkait dengan aturan perundang-undangan mengakibatkan remaja dapat menjadi pelaku atau korban dari media sosial tersebut.

Terlebih lagi ada oknum-oknum yang sengaja memanfaatkan media sosial untuk melakukan tindakan kriminal dan menjadikan remaja sebagai sasaran empuk kejahatan mereka. Di samping itu remaja juga harus berhati-hati dalam mem-posting atau menyebarkan informasi yang bersifat tuduhan dan mengundang SARA (Suku, Agama, Ras, Antargolongan) dan juga yang berisi kebohongan di media sosial. Hal ini berkaitan dengan UU ITE yang dapat dikenakan sanksi hukum bagi pelanggarnya.

Pemerintah melalui kementerian Komunikasi dan Informatika pada tanggal 25 Maret 2008 telah mengeluarkan produk hukum yaitu Undang-Undang Informasi dan Transaksi Elektronik atau yang bisa disingkat dengan UU ITE yang dimaksudkan salah satunya mengatur untuk tetap bijak menggunakan sosial media. Sebagaimana yang disaksikan melalui berita di media masa baik itu televisi, surat kabar maupun berita di internet sudah banyak contoh kasus-kasus tentang pelanggaran UndangUndang Informasi dan Transaksi Elektronik ( UU ITE ), tidak sedikit masyarakat sipil yang sudah menjadi korban jeratan hukum.

Adapun yang menjadi mitra dalam pengabdian ini adalah kalangan Remaja yang terdapat di SMA Dharma Wanita Prov.Sumut dan SMP Dharma Wanita Pelwildasu Medan. Rentannya remaja sebagai generasi penerus bangsa terhadap berbagai dampak negatif dari media sosial yang terkadang tidak disadari oleh remaja itu sendiri. Serta kurangnya pengetahuan remaja tentang perundangundangan yang berkaitan dengan informasi dan teknologi sebagaimana yang dijelaskan di atas. Adapun permasalahan yang akan di bahas antara lain: Bagaimana dampak media sosial bagi remaja ditinjau dari Undang-undang Informasi dan Transaksi Elektronik? Bagaimana penyelesaian terhadap permasalahan hukum yang dialami oleh remaja terkait dengan penggunaan media sosial?

\section{METODE}

Seperti telah disebutkan pada bab Pendahuluan bahwa penggunaan media sosial yang semakin meningkat terutama di kalangan remaja dengan memposting berbagi macam informasi dan potensi terjadinya akibat hukum dari penggunaan media sosial yang tidak bijak. Maka pentingnya dilakukan kegiatan penyuluhan hukum terhadap dampak penggunaan media sosial.

Adapun tahapan-tahapan kegiatan yang akan dilakukan adalah 
Lubis, TM. et al. Penyuluhan Hukum Dampak Media Sosial Bagi Remaja.

1) melakukan koordinasi terlebih dahulu pada pihak sekolah untuk mensosialisasikan rencana kegiatan penyuluhan hukum. Tujuan sosialisasi ini adalah untuk mengenalkan program kegiatan yang akan dilakukan.

2) Melakukan sosialisasi program kepada pihak sekolah sekaligus menyebarkan angket. Tujuannya untuk mengukur tingkat pemahaman siswa yakni SMA Dharma Wanita Persatuan Prov.Sumut dan SMP Dharma Wanita Pelwildasu Medan terhadap dampak penggunaan media sosial.

3) Dalam kegiatan ini akan melibatkan 3 mahasiswa sehingga mahasiswa akan membantu pelaksanaan kegiatan pengabdian untuk masyarakat ini.

4) Menyiapkan materi penyuluhan dan buku panduan

5) Melaksanakan kegiatan penyuluhan hukum di dua sekolah yaitu SMA Dharma Wanita Persatuan Prov.Sumut dan SMP Dharma Wanita Pelwildasu Medan

6) Melakukan evaluasi dengan menyebarkan angket untuk melihat tingkat pemahaman peserta setelah penyuluhan dilakukan.

\section{HASIL DAN PEMBAHASAN}

Pengabdian pada masyarakat dengan dana BPPTN USU tahun 2018 dilakukan pada dua sekolah yaitu di SMA Dharma Wanita Prov.Sumut dan SMP Dharma Wanita Pelwildasu Medan yang terletak di Kecamatan Medan Selayang yakni di Jalan Melati II Ujung No.30 Komplek Pemdasu Tanjung Sari, Kelurahan Sempakata-Kecamatan Medan Selayang. Sebelum penyuluhan hukum dilakukan di dua sekolah tersebut dipersiapkan terlebih dahulu Buku Saku yang akan di bagikan kepada peserta penyuluhan hukum tersebut. Buku saku tersebut berisi ketentuanketentuan mengenai dampak media sosial bagi remaja. Untuk memudahkan penyuluhan hukum tersebut dipersiapkan pula bahan berupa power point yang dapat dilihat langsung oleh peserta ketika melakukan penyuluhan hukum.
Penyuluhan hukum tahap pada I di lakukan SMP Dharma Wanita Pelwildasu Medan yang terletak di di Kecamatan Medan Selayang yakni di Jalan Melati II Ujung No.30 Komplek Pemdasu Tanjung Sari, Kelurahan Sempakata-Kecamatan Medan Selayang dengan jumlah peserta 50 (lima puluh). Sebelum penyuluhan di mulai dibagikan angket dan buku saku kepada peserta penyuluhan.

$$
\text { Kegiatan ini diawali dengan }
$$
pembukaan oleh tim penyuluh, kemudian dilanjutkan dengan kata sambutan dari pihak sekolah SMP Dharma Wanita Pelwildasu Medan. Acara kemudian dilanjutkan penyampaian materi penyuluhan yang disampaikan oleh pemateri. Pada saat penyampaian materi juga diputarkan video yang berkaitan dengan dampak penggunaan media sosial. Selanjutnya dilakukan diskusi dengan siswa SMP Dharma Wanita Pelwildasu Medan terhadap tanggapan video tersebut. Kemudian penyampaian materi dilanjutkan kembali. Para siswa sangat antusias. Sesi terakhir ditutup dengan Tanya jawab dan foto bersama.

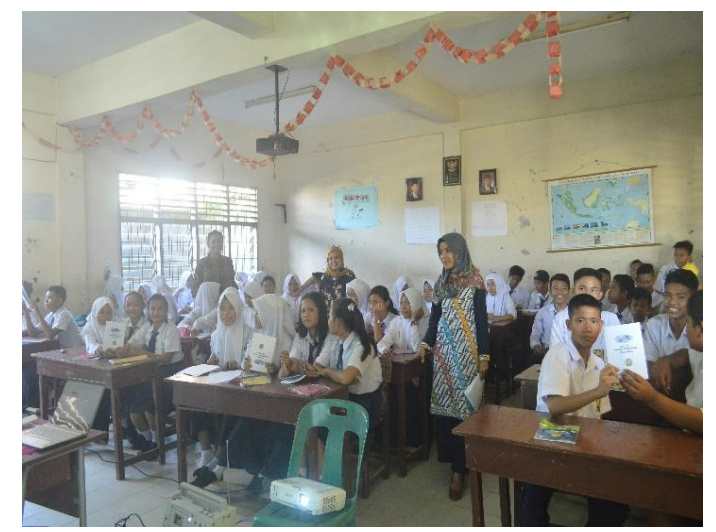

(Gambar-1. Pemberian Buku Saku kepada Peserta) 
Lubis, TM. et al. Penyuluhan Hukum Dampak Media Sosial Bagi Remaja.

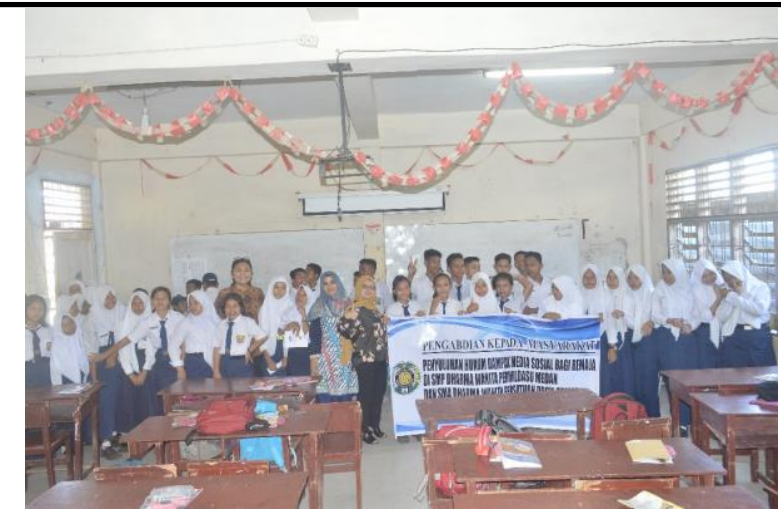

(Gambar-2. Foto Bersama siswa SMP Dharma Wanita Pelwildasu Medan)

Penyuluhan Tahap II di SMA Dharma Wanita Prov.Sumut yang terletak di Kecamatan Medan Selayang yakni di Jalan Melati II Ujung No.30 Komplek Pemdasu Tanjung Sari, Kelurahan SempakataKecamatan Medan Selayang dilakukan pada tanggal 20 Juli 2018 dengan jumlah peserta 50 (lima puluh). Sebelum dilakukannya penyuluhan tim penyuluh sudah melakukan koordinasi kepada mitra untuk memastikan jadwal yang sesuai untuk melakukan penyuluhan di SMA Dharma Wanita Prov.Sumut. Sebelum penyuluhan di mulai dibagikan angket dan buku saku kepada peserta penyuluhan.

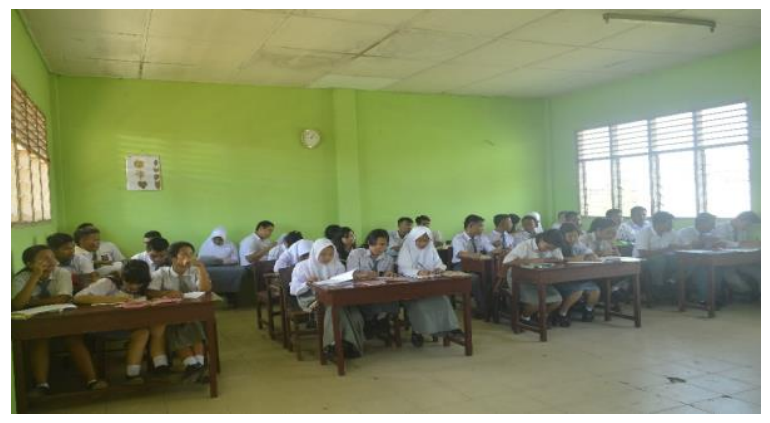

(Gambar-3. Pemberian Buku Saku kepada Peserta

Kegiatan ini diawali dengan pembukaan oleh tim penyuluh, kemudian dilanjutkan dengan kata sambutan dari pihak sekolah SMA Dharma Wanita Prov.Sumut. Acara kemudian dilanjutkan penyampaian materi penyuluhan yang disampaikan oleh pemateri. Pada saat penyampaian materi juga diputarkan video yang berkaitan dengan dampak penggunaan media sosial.

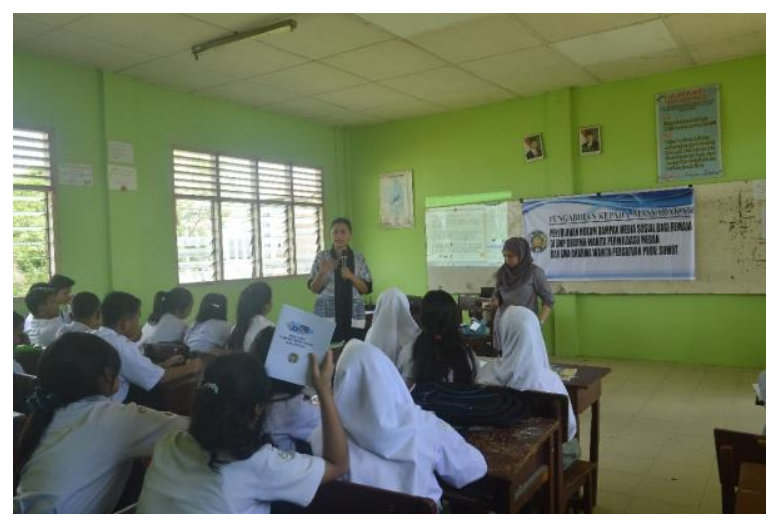

(Gambar-4. Sesi Diskusi bersama siswa SMA Dharma Wanita Prov.Sumut)

Selanjutnya dilakukan diskusi dengan siswa SMA Dharma Wanita Prov.Sumut terhadap tanggapan video tersebut. Kemudian penyampaian materi dilanjutkan kembali. Para siswa sangat antusias. Sesi terakhir ditutup dengan Tanya jawab dan foto bersama.

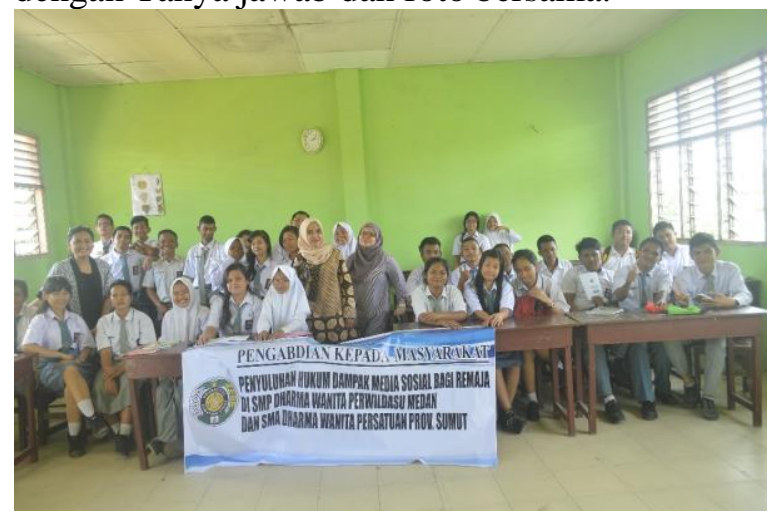

(Gambar-5. Foto Bersama siswa SMA Dharma Wanita Prov.Sumut)

\section{KESIMPULAN}

Penyuluhan hukum dampak media sosial bagi remaja dapat memberikan pemahaman yang mendalam dan komprehensif mengenai perundang-undangan yang terkait dengan penggunaan media sosial sehingga dapat menggunakan media sosial secara bijak. Dari hasil evaluasi, kegiatan pelatihan ini dapat dikatakan cukup berhasil. Dari pertanyaan 
Lubis, TM. et al. Penyuluhan Hukum Dampak Media Sosial Bagi Remaja.

yang diajukan peserta tergambar peningkatan pemahaman peserta terhadap hukum tentang dampak media sosial bagi remaja dan diharapkan dapat segera terbentuk kelompok binaan yang dapat membantu masyarakat dalam menjawab berbagai persoalan yang berkaitan dengan dampak media sosial bagi remaja di lingkungan tersebut.

\section{UCAPAN TERIMA KASIH}

Artikel ini merupakan salah satu hasil dari Program Pengabdian kepada Masyarakat yang Dibiayai oleh BPPTN Universitas Sumatera Utara Sesuai dengan Surat Perjanjian Penugasan Pelaksanaan Pengabdian kepada Masyarakat Program Mono Tahun (Dosen Muda) Tahun Anggaran 2018 Nomor: 107/ UN5.2.3.2.1/ PPM /2018, Tanggal 26 Maret 2018. Oleh karena itu, diucapkan terima kasih kepada Rektor Universitas Sumatera Utara atas dukungan dana dan fasilitas yang diberikan. Terima kasih juga kepada Mitra pada kegiatan pengabdian ini.

\section{REFERENSI}

Andriati, Syarifah Lisa, A Novelty of Impact of Social Media from the Legal Perspective, Jurisprudence, Vol. 8 No. 1 Juni 2018.

Grant, August E \& Meadows, Jennifer $\mathrm{H}$. (eds.) (2010).Communication Technology Update and Fundamental.12th Edition.Boston: Focal Press.

Hamzah, Andi, Aspek-Aspek Pidana di Bidang Komputer, Sinar Grafika, Jakarta, 1990.

Raharjo, Agus, Cyber Crime Pemahaman Dan Upaya Pencegahan Kejahatan

Berteknologi, Bandung, Citra Aditya Bakti, 2002.

Harlina, Yuni, "Dampak Komunikasi Jejaring Sosial Terhadap Kehidupan Perkawinan Dalam Islam", Vol.5 No.1, http://ejournal.uin-suska.ac.id.

Kaplan, Andreas M.; Michael Haenlein (2010) "Users of the world, unite! The challenges and opportunities of Social Media". Business Horizons 53(1): 59-68.

Tim Pusat Humas Kementerian Perdagangan RI, Panduan Optimalisasi Media Sosial untuk Kementerian Perdagangan RI, 2014. 